\title{
Heavy metal concentrations of selected public parks of Istanbul City
}

\author{
Goksel Demir ${ }^{1}$, H. Kurtulus Ozcan ${ }^{2}$, Huseyin Ozdemir ${ }^{3}$, Ali Osman Pektas ${ }^{3}$, Ilker Oruc $^{4}$ and Muhammet Buyukyildiz ${ }^{5}$ \\ ${ }^{1}$ Kirklareli University, Architecture Faculty, Department of Urban and Regional Planning, Kirklareli- Turkey \\ ${ }^{2}$ Istanbul University, Engineering Faculty, Department of Environ. Engineering, 34320 Avcilar, Istanbul-Turkey \\ ${ }^{3}$ Bahcesehir University, Faculty of Engineering, Department of Environ. Engineering, 34349 Besiktas, Istanbul-Turkey \\ ${ }^{4}$ Kirklareli University, Vocational College of Technical Sciences, Kirklareli-Turkey \\ ${ }^{5}$ Istanbul Grater Municipality Quality Control Laboratory, Istanbul-Turkey
}

\begin{abstract}
Many cities, especially larger metropolises, parks are very important recreational areas where people usually have closer contact with flora. Therefore, the pollution level in the parks can have a greater effect on human health. Heavy metals are ubiquitous with the environment, as a result of both natural and anthropogenic activities, and humans are exposed to them through various pathways. Essentially, these areas are assumed to be less exposed to routine contaminants, but especially in metropolises, this assumption could prove false considering these areas are stuck within the confines of a city full of pollutant activity such as intense traffic. In this study; the relationships between heavy metal pollution levels $(\mathrm{Cd}, \mathrm{Cr}, \mathrm{Cu}, \mathrm{Ni}, \mathrm{Pb}, \mathrm{Zn})$ and the $\mathrm{pH}$ and electrical conductivity (EC) of soil samples were investigated from the parks on the Asian side of Istanbul. For this purpose, the most frequently visited 16 parks were selected as sampling sites. In the second part of the study, linear correlation is used for the data analysis.
\end{abstract}

\section{Introduction}

In addition to air and water, living organisms also need soil to survive. Land is an important environmental component for the future of living organisms. Unfortunately, the land is contaminated by different sources gradually. One of the most significant types of pollution on land is heavy metal pollution, thus this subject has become a focus point of environmental science. Among all of the researched heavy metal pollutants, $\mathrm{Cu}, \mathrm{Cd}, \mathrm{Ni}, \mathrm{Zn}, \mathrm{Co}$ and $\mathrm{Pb}$ become the most frequently examined, as they have a wide range of applications [1, 2, 3, 4]. Because of crop production over contaminated soils and contaminated pastures, heavy metals are carried up the food chain, and this process is therefore significantly affecting all living organisms in the ecosystem - with human beings as no exception - in a dangerous manner [5].

The earth on which we live and produce our food is polluted for many reasons, such as irresponsible agricultural methods, mining operations, residential operations and industrial applications of methods in agriculture. When the soil is polluted by the wastewater, this situation can lead dangerous consequences via groundwater contamination. The most important and known effect of soil pollution by the perspective of environmental health is the mobility of pollutants from soil to plants and then from plants to animals and people. Additionally, there are many health risks associated with physical exposure to contaminated soil, or digestion of contaminated dust - especially digestion of evaporating mercury and arsenic, in the soil [6]. Some important physical and chemical properties of soil, such as texture, cation exchange capacity, $\mathrm{pH}$ value and the amount of organic matter within the soil, are important parameters that affect the heavy metal accumulation rate of the soil in question [7]. Heavy textured soils are particularly able to absorb high ratios of heavy metal since they have a high exchange capacity of cation. Furthermore, soils that are rich in organic matter can much more quickly absorb heavy metals and cause the formation of hard-soluble compound.

Heavy metals are spread into the atmosphere from many different sources and different processing stages. In particular, heavy metals released from various sources, such as petrochemical, paper, energy, transportation and fertilizer industries, can cause damage to the ecological balance by following the path of dry and wet deposition to the surface and surface waters, and then mixed up in groundwater [2-8]. Generally, soil is able to neutralize the high level elements in it and so prevent aquatic organisms from the toxic effects of these elements. But, there could be heavy metal contamination close to the domestic and industrial waste places, heavy traffic roads and the unconsciously fertilized agricultural areas [9]. Common activities that increase the heavy metal accumulation of soil include the use of heavy metal-containing fertilizers and pesticides in agricultural activities and landscape studies, using high content heavy metal surface waters for irrigation and the use of heavy metal contaminated sew- 
age sludge and wastes in order to increase the soil productivity. Another increasing factor of soil heavy metal accumulation is rainwater that has been polluted by flue and exhaust gas emissions [10].

In literature, the heavy metal studies that focused on recreational areas and parks are rare. Kabala et al. [11] examined total concentrations of $\mathrm{Cu}, \mathrm{Pb}$ and $\mathrm{Zn}$ from 180 small family gardens of Poland and found that up to $35 \%$ of soils are excessively contaminated and require reclamation. Rajan et al. [12] investigated the heavy metal chemical changes before and after a monsoon at the recreational park tributaries in Pahang, Malaysia. They took water samples from 5 tributaries 6 times (3 times before, and 3 after the monsoon) and monitored the temperature, $\mathrm{pH}$, oxygen derivation and the quantities of 8 heavy metals (Ag, $\mathrm{Cd}, \mathrm{Cu}, \mathrm{Cr}, \mathrm{Fe}, \mathrm{Ni}, \mathrm{Pb}$, and $\mathrm{Zn}$ ). They too, also concluded that the water supply in the investigated National Parks have acceptable quality for recreational purposes. On the other hand, the usage of multivariate statistical analysis in heavy metal studies is very common. Arslan et al. [13] used cluster analysis and principal component analysis to comprehend the relationships between salinity, sodicity, and some soil properties in irrigated areas of the Bafra Plain, Turkey. They took 86 samples from different depths of 0-30 cm and $30-60 \mathrm{~cm}$ and used cluster analysis to group the sampling sites. Similarly, Liu et al. [14] used principal component analysis and cluster analysis to evaluate the heavy metal concentrations in soils around two gauge hills from Zhuxiangzhuang coal mine, northern Anhui province, China. Shahbaz et al. [15] analyzed the egg contents, prey and soil samples of little egret and cattle egret from two headworks to assess the importance of prey and habitat contamination as an exposure source for heavy metals. They used Correlation Analysis and Hierarchical Agglomerative Cluster Analysis (HACA) and identified relatively similar associations of metals and their source identification. Zheng et al. [16] used multivariate statistical analysis (correlation analysis, principal-components analysis, and clustering analysis) to investigate the heavy metal content of particulate matter in the city of Guangzhou in southern China by using samples of urban foliage near 36 pedestrian bridges.

The purpose of this study is investigating the relationship between heavy metal pollution levels $(\mathrm{Cd}, \mathrm{Cr}$, $\mathrm{Cu}, \mathrm{Ni}, \mathrm{Pb}, \mathrm{Zn}$ ) and the $\mathrm{pH}$ and electrical conductivity (EC) of soil samples from the parks on the Asian side of Istanbul. Linear correlation analysis is used for this purpose.

\section{Material and method}

\subsection{Sampling procedure}

This study was conducted in the city of Istanbul, the most important city in Turkey in terms of its industry and economy. Beside the intensive industrial facilities and economic mobility of the city, the high population intensifies the problems of environmental pollution. Istanbul is an intercontinental city, which is between Europe and Asia. The European part of the city is called the European side and the Asian part is called the Asian Side. According to a report which is prepared by the Turkish Statistical Institute (TSI), the city has a total population of 13.6 million people and $64.7 \%$ of this population is living in the European side while the other $35.3 \%$ living in the Anatolian side [17]. Since most of the parks are isolated places when compared with general urban areas, it was intended to select the most probably contaminated parks in order to show the relationship of heavy metal concentrations. For this purpose, the most frequently visited 16 parks were selected as sampling sites. The selected sampling sites (parks) are in the vicinity of the intense urban activity. As a result of this condition, selected parks are also near intense traffic roads and industrial activities. The texture of soils which were measured in this study is generally sandy, clayey, loamy, slight alkali, saltless, and contains low amounts of lime and medium amounts of organical material [18]. In the site selection phase of the study, this situation is taken into consideration and an assumption is made that these areas should be much more exposed to heavy metal contaminations, especially sourcing from the air and flue gas exhaust emissions. For sampling areas, another default pollutant factor is annual maintenance works such as fertilization and soil regulation processing works. After determining the sample sites, the soil samples were taken from two levels of depths $(0-20 \mathrm{~cm}$ and $20-40 \mathrm{~cm})$ by considering soil color, the slope, plant diversity and the difference of activities on the ground. For each determined sampling point, a sufficient number of soil samples were taken to that rep-resents corresponding parcel. Afterwards, these soil samples were mixed to obtain homogenous composite, and at least one kilogram of the sample was taken from each homogenous composition. The sampling points and sampling numbers are given in Table 1.

Table 1. Sampling point notation and the number of sampling.

\begin{tabular}{|c|c|c|c|}
\hline \multirow[t]{2}{*}{ Sampling points } & \multirow[t]{2}{*}{ Notation } & \multicolumn{2}{|c|}{ Number of soil samples } \\
\hline & & $0-20 \mathrm{~cm}$ & $20-40 \mathrm{~cm}$ \\
\hline Kadıköy Moda Parkı & P1 & 23 & 23 \\
\hline Göztepe Parkı & $\mathrm{P} 2$ & 11 & 11 \\
\hline Osman Gazi Korusu & P3 & 23 & 23 \\
\hline İdealtepe Park1 & $\mathrm{P} 4$ & 14 & 14 \\
\hline Gözdağ1 Park1 & P5 & 17 & 17 \\
\hline Pendik Üst Kaynarca & P6 & 15 & 15 \\
\hline Tuzla Botaş Parkı & P7 & 18 & 18 \\
\hline Büyükçamlıca Parkı & P8 & 16 & 16 \\
\hline Küçükçamlıca Parkı & P9 & 20 & 20 \\
\hline Millet Park1 & P10 & 6 & 6 \\
\hline Beykoz Korusu & P11 & 15 & 15 \\
\hline Beykoz Çayırı & P12 & 10 & 10 \\
\hline Hidiv Kasrı & P13 & 9 & 9 \\
\hline Fethipaşa Korusu & P14 & 11 & 11 \\
\hline Doğancılar Parkı & P15 & 4 & 4 \\
\hline Üsküdar Sahil Parkı & P16 & 7 & 7 \\
\hline Total & & 219 & 219 \\
\hline
\end{tabular}

\subsection{Sampling analysis}


When Heavy metal analysis based on the ISO 11464 [19] standards, soil samples were subjected to a drying process in an air circulated oven in which the loss of moisture or 24 -hour did not exceed $5 \%$ by weight (on average $35-40^{\circ} \mathrm{C}$ ). To ensure homogeneity, soil samples have been prepared for analysis by grinding the samples with wood and porcelain mortar and hammers until the particle diameter is convenient to pass under a $12: 18 \mathrm{~mm}$ sieve. Wood and porcelain mortars and hammers were used to prevent from metal contamination. Then, 0.2-0.3 $\mathrm{g}$ weighing analysis samples were taken over teflon vessels from this homogenized soil samples, and a $10 \mathrm{ml}$ acidic solution $\left(1: 3 \mathrm{HNO}_{3}\right.$ : $\left.\mathrm{HCl}\right)$ was added on this analysis sample. After a one hour digestion process under a Microwave power (Berghof Speed), the resulting extract was then diluted with distilled water at the desired rate and has been made ready for measurements. The heavy metal $(\mathrm{Cd}, \mathrm{Cr}, \mathrm{Cu}, \mathrm{Ni}, \mathrm{Pb}$, and $\mathrm{Zn})$ concentrations were measured by using the ICP-OES instrument (Perkin Elmer, Optima 2100 [20].

\section{$2.3 \mathrm{pH}$ and Electrical Conductivity analysis}

To measure the $\mathrm{pH}$ values of soil samples first, $5 \mathrm{ml}$ soil analysis samplings have taken and $25 \mathrm{ml}$ of pure water was added on to obtain a suspension. Subsequently, this suspension was stirred vigorously and has been waited from 2 hour to 18 hour to access stabilization period of suspension. After stabilization, the $\mathrm{pH}$ was measured by using an appropriate instrument (WTW Multi 340i) on the filtrated suspension. The electrical conductivity of the soil was also measured with the same instrument. Before measurement $20 \mathrm{~g}$ of analysis samples were taken from a homogenized soil mixture. Pure water is used to suspensionized these samples, then suspensions are shaken for 30 minutes at $180 \mathrm{rpm}$ agitation rate value. After agitation, the suspension was filtrated and the Electrical Conductivity (EC) values were measured with the instrument WTW Multi 340i.

\section{Result and discussion}

\subsection{Heavy metals of soil samples}

The mean values of heavy metal concentrations for each sampling point (parks) are presented in Table 2 and 3 related to the soil sample depths as $0-20 \mathrm{~cm}$ and $20-40$ $\mathrm{cm}$, respectively. In nature; cadmium and zinc are associated with one another. Cadmium is obtained as a by-product during the refination of zinc.

Table 2. The heavy metal concentrations of samples in the depth range of $0-20 \mathrm{~cm}$

\begin{tabular}{ccccccccc}
\hline & $p H$ & $E C$ & $C d$ & $C r$ & $C u$ & $N i$ & $P b$ & $\mathrm{Zn}$ \\
\hline & & $\mu m h o$ & $m g /$ & $m g /$ & $m g /$ & $m g /$ & $m g / k$ & $m g / k$ \\
& & $s / c m$ & $k g$ & $k g$ & $k g$ & $k g$ & $g$ & $g$ \\
\cline { 2 - 9 } P1 & 7.8 & 121.1 & 0.3 & 45. & 27. & 26. & 14.1 & 63.4 \\
& 30 & 30 & 10 & 810 & 780 & 810 & 50 & 00 \\
P2 & 7.7 & 118.3 & 0.3 & 54. & 19. & 35. & 12.3 & 82.3 \\
P3 & 90 & 60 & 90 & 530 & 760 & 560 & 40 & 20 \\
& 7.2 & 123.3 & 1.1 & 47. & 38. & 30. & 35.5 & 68.1
\end{tabular}

\begin{tabular}{|c|c|c|c|c|c|c|c|c|}
\hline & 90 & 20 & 40 & 810 & 260 & 820 & 20 & 60 \\
\hline \multirow{2}{*}{ P4 } & 7.6 & 230.9 & 0.3 & 52. & 38. & 33. & 15.6 & 69.6 \\
\hline & 70 & 30 & 20 & 770 & 600 & 820 & 10 & 60 \\
\hline \multirow{2}{*}{ P5 } & 7.6 & 142.0 & 2.6 & 44. & 37. & 29. & 154. & 189. \\
\hline & 40 & 00 & 70 & 890 & 180 & 500 & 420 & 690 \\
\hline \multirow{2}{*}{ P6 } & 8.0 & 159.2 & 0.8 & 48. & 37. & 37. & 28.3 & 115. \\
\hline & 40 & 00 & 90 & 630 & 110 & 210 & 90 & 480 \\
\hline \multirow{2}{*}{ P7 } & 7.7 & 188.4 & 0.3 & 49. & 21. & 38. & 19.7 & 53.5 \\
\hline & 30 & 40 & 20 & 240 & 430 & 910 & 20 & 10 \\
\hline \multirow{2}{*}{ P8 } & 6.6 & 146.9 & 0.4 & 11. & 31. & 31. & 26.8 & 63.9 \\
\hline & 50 & 40 & 20 & 960 & 490 & 740 & 80 & 30 \\
\hline \multirow{2}{*}{$\mathrm{P}$} & 7.4 & 149.4 & 0.2 & 53. & 27. & 30. & 24.5 & 55.7 \\
\hline & 20 & 00 & 70 & 050 & 880 & 250 & 60 & 70 \\
\hline P1 & 7.9 & 266.6 & 0.1 & 42. & 35. & 34. & 20.7 & 61.9 \\
\hline 0 & 40 & 70 & 40 & 20 & 610 & 570 & 10 & 30 \\
\hline P1 & 7.1 & 127.3 & 2.5 & 66. & 50. & 64. & 33.0 & 118. \\
\hline 1 & 10 & 30 & 40 & 270 & 830 & 310 & 20 & 690 \\
\hline $\mathrm{P} 1$ & 7.5 & 228.2 & 1.5 & 50. & 50. & 40 & 28.1 & 101. \\
\hline 2 & 30 & 00 & 60 & 260 & 700 & 980 & 10 & 180 \\
\hline P1 & 6.5 & 148.3 & 1.7 & 68. & 45 & 54. & 36.9 & 107. \\
\hline 3 & 50 & 30 & 60 & 040 & 640 & 130 & 50 & 110 \\
\hline $\mathrm{P} 1$ & 7.2 & 160.1 & 1.4 & 83. & 53. & 59. & 36.3 & 111. \\
\hline 4 & 40 & 80 & 80 & 540 & 450 & 090 & 60 & 290 \\
\hline $\mathrm{P} 1$ & 7.6 & 204.2 & 1.5 & 51. & 54. & 44. & 112. & 129. \\
\hline 5 & 40 & 50 & 40 & 040 & 400 & 510 & 450 & 100 \\
\hline P1 & 7.6 & 257.7 & 1.1 & 44. & 30. & 35. & 24.4 & 79.4 \\
\hline 6 & 30 & 10 & 10 & 160 & 550 & 400 & 60 & 30 \\
\hline me & 7.4 & 173.2 & 1.0 & 54. & 37. & 39. & 38.9 & 91.9 \\
\hline$a n$ & 81 & 74 & 53 & 664 & 542 & 226 & 78 & 16 \\
\hline$m i$ & 6.5 & 118.3 & 0.1 & 42. & 19. & 26. & 12.3 & 53.5 \\
\hline$n$ & 50 & 60 & 40 & 620 & 760 & 810 & 40 & 10 \\
\hline$m a$ & 8.0 & 266.6 & 2.6 & 83. & 54. & 64. & 154. & 189. \\
\hline$x$. & 40 & 70 & 70 & 540 & 640 & 310 & 420 & 690 \\
\hline$S$ & 0.4 & 49.63 & 0.8 & 11. & 10 & 11. & 38.4 & 36.0 \\
\hline DD & 24 & 6 & 14 & 625 & 979 & 003 & 32 & 47 \\
\hline
\end{tabular}

Cadmium compounds are used as stabilizers or pigments in; the coating process of metals, alkali coils, several metal alloys such as copper and in plastics. Because of this, the cadmium concentration is at high levels where the places where industrial activities are intense

Table 3. The heavy metal concentrations of samples in the depth range of $20-40 \mathrm{~cm}$

\begin{tabular}{ccccccccc}
\hline & $p H$ & $E C$ & $C d$ & $C r$ & $C u$ & $N i$ & $P b$ & $Z n$ \\
\hline & & $\mu m h o$ & $m g /$ & $m g /$ & $m g /$ & $m g /$ & $m g / k$ & $m g / k$ \\
& & $s / c m$ & $k g$ & $k g$ & $k g$ & $k g$ & $g$ & $g$ \\
\cline { 2 - 9 } P1 & 8.1 & 161.3 & 0.3 & 52. & 33. & 32. & 18.0 & 68.7 \\
& 90 & 00 & 70 & 510 & 920 & 860 & 60 & 20 \\
P2 & 8.0 & 122.2 & 0.3 & 58. & 19. & 37. & 14.7 & 71.5 \\
& 00 & 70 & 50 & 190 & 170 & 130 & 60 & 00 \\
P3 & 7.2 & 126.4 & 1.0 & 40. & 38. & 28. & 25.7 & 62.0 \\
& 40 & 20 & 40 & 500 & 570 & 930 & 40 & 10 \\
P4 & 7.6 & 203.3 & 0.2 & 46. & 33. & 30. & 11.5 & 61.2 \\
& 90 & 60 & 50 & 560 & 610 & 500 & 70 & 20 \\
P5 & 7.6 & 115.8 & 2.7 & 43. & 31. & 29. & 142. & 173. \\
& 60 & 00 & 80 & 640 & 580 & 470 & 220 & 860 \\
P6 & 8.1 & 161.2 & 0.8 & 46. & 37. & 35. & 24.7 & 122. \\
& 30 & 70 & 90 & 340 & 090 & 030 & 10 & 360 \\
P7 & 8.0 & 161.6 & 0.3 & 48. & 23. & 35. & 28.2 & 58.9 \\
& 40 & 70 & 90 & 280 & 390 & 890 & 30 & 90 \\
P8 & 6.7 & 153.7 & 0.3 & 68. & 31. & 43. & 23.5 & 57.9 \\
& 00 & 50 & 50 & 860 & 490 & 080 & 50 & 20 \\
P9 & 7.3 & 135.5 & 0.2 & 45. & 28. & 25. & 25.4 & 51.1 \\
& 60 & 50 & 60 & 610 & 730 & 280 & 40 & 10
\end{tabular}




\begin{tabular}{ccccccccc}
$\mathrm{P} 1$ & 7.9 & 250.5 & 0.1 & 43. & 31. & 29. & 25.2 & 54.2 \\
0 & 90 & 00 & 20 & 020 & 850 & 700 & 60 & 80 \\
$\mathrm{P} 1$ & 7.1 & 129.1 & 2.4 & 59. & 48. & 58. & 30.2 & 115. \\
1 & 20 & 30 & 90 & 380 & 670 & 010 & 10 & 540 \\
$\mathrm{P} 1$ & 7.8 & 213.7 & 1.6 & 44. & 45. & 38. & 23.4 & 93.7 \\
2 & 90 & 00 & 30 & 930 & 790 & 500 & 00 & 80 \\
$\mathrm{P} 1$ & 7.0 & 58.78 & 2.2 & 68. & 48. & 63. & 26.9 & 94.2 \\
3 & 10 & 0 & 10 & 830 & 560 & 680 & 20 & 50 \\
$\mathrm{P} 1$ & 7.2 & 166.1 & 1.5 & 76. & 53. & 61. & 33.8 & 110. \\
4 & 70 & 80 & 10 & 430 & 360 & 250 & 00 & 070 \\
$\mathrm{P} 1$ & 7.9 & 183.0 & 1.6 & 55. & 60. & 45. & 120. & 131. \\
5 & 10 & 00 & 60 & 710 & 680 & 770 & 690 & 880 \\
$\mathrm{P} 1$ & 7.9 & 195.7 & 1.1 & 58. & 30. & 37. & 30.0 & 78.0 \\
6 & 90 & 10 & 80 & 900 & 400 & 830 & 90 & 30 \\
\hline$m e$ & 7.6 & 158.6 & 1.0 & 53. & 37. & 39. & 37.7 & 87.8 \\
$a n$ & 37 & 49 & 92 & 606 & 304 & 557 & 91 & 45 \\
$m i$ & 6.7 & 58.78 & 0.1 & 40. & 19. & 25. & 11.5 & 51.1 \\
$n$. & 00 & 0 & 20 & 500 & 170 & 280 & 70 & 10 \\
$m a$ & 8.1 & 250.5 & 2.7 & 76. & 60. & 63. & 142. & 173. \\
$x$. & 90 & 00 & 80 & 430 & 680 & 680 & 220 & 860 \\
$S D$ & 0.4 & 45.54 & 0.8 & 10. & 11. & 11. & 37.2 & 34.8 \\
& 57 & 3 & 69 & 728 & 251 & 917 & 04 & 09 \\
\hline & & & & & & & &
\end{tabular}

As shown in Table 2, for all parks and at the depth between $0-20 \mathrm{~cm}$, the overall mean values of cadmium concentration were $1.050 \mathrm{mg} / \mathrm{kg}$, whereas, the minimum and the maximum values appeared to be $0.140 \mathrm{mg} / \mathrm{kg}$ and $2.670 \mathrm{mg} / \mathrm{kg}$ at the parks $\mathrm{P} 10$ and $\mathrm{P} 5$, respectively. Similarly, the mean cadmium concentration is 1.09 $\mathrm{mg} / \mathrm{kg}$ at the depth level $20-40 \mathrm{~cm}$ (Table 3) and the minmax Cd concentration are observed in P10 and P5 parks, respectively. The mean $\mathrm{Zn}$ concentration of $0-20 \mathrm{~cm}$ depth is $91.920 \mathrm{mg} / \mathrm{kg}$ where the maximum $\mathrm{Zn}$ concentrations were measured from the samples of P5 for both depth ranges. For $0-20 \mathrm{~cm}$ depths the minimum $\mathrm{Zn}$ concentration is observed at $\mathrm{P} 7$ and in the depth range of $20-40 \mathrm{~cm}$ the minimum concentration of $\mathrm{Zn}$ may be observed in P9 (Table 2-3).

Mostly, the chromium exists in the form of insoluble chromic acid $\mathrm{Cr}_{2} \mathrm{O}_{3} \mathrm{H}_{2} \mathrm{O}$ in soil and this form is not mobile in soil structure. The washing process of soil via irrigation and precipitation increases the mobility of chromium depending on whether the chromium has formed soluble compounds or not. As seen in Table 2, the overall mean value of $\mathrm{Cr}$ is $54.664 \mathrm{mg} / \mathrm{kg}$. The minimum and maximum concentrations of $\mathrm{Cr}$ are observed in $\mathrm{P} 10$ and P14, respectively. For the depth level $20-40 \mathrm{~cm}$, the overall mean value is calculated as $53.606 \mathrm{mg} / \mathrm{kg}$, whilst the minimum and maximum concentrations are found in P3 and P14, respectively. The overall mean concentrations of $\mathrm{Cu}$ are $37.542 \mathrm{mg} / \mathrm{kg}$ and $37.304 \mathrm{mg} / \mathrm{kg}$ for the level depths of $0-20 \mathrm{~cm}$ and $20-40 \mathrm{~cm}$, respectively. For both levels, the minimum and the maximum concentrations are measured in the parks P2 and $\mathrm{P} 15$. The Ni concentrations mean values vary from $39.226 \mathrm{mg} / \mathrm{kg}$ to $39.557 \mathrm{mg} / \mathrm{kg}$ with changing depth levels from $0-20 \mathrm{~cm}$ to $20-40 \mathrm{~cm}$. In near surface levels, the minimum and maximum $\mathrm{Ni}$ concentrations are observed in P1 and P11, and for deep level samples minimum and maximum levels are measured in the samples of the $\mathrm{P} 9$ and $\mathrm{P} 13$, respectively.

In this study; another investigated heavy metal compound was $\mathrm{Pb}$. The majority of the atmospheric $\mathrm{Pb}$ is revealed as a result of the combustion of alkyl-lead that has been used as an additive in fuels. $\mathrm{Pb}$ emissions released into the atmosphere is condensed in the soil thanks to precipitation, and then subsequently becomes party to the entire food chain via plants and animals. The $\mathrm{Pb}$ mean concentrations of the parks are $38.978 \mathrm{mg} / \mathrm{kg}$ and $37.791 \mathrm{mg} / \mathrm{kg}$ for shallow and deep levels, respectively. The minimum and maximum $\mathrm{Pb}$ concentrations are observed in P2 and P5 for $0-20 \mathrm{~cm}$ depths, whereas these values are observed in the parks P4 and P5 for the depth level of 20-40 cm (Table 2-3). Limit values for related heavy metals in national soil pollution control regulation were given in Table 4.

Table 4. Sampling point notation and the number of sampling.

\begin{tabular}{|c|c|c|}
\hline Pollutant & $\begin{array}{c}\text { Limit value for } \\
\text { skin exposure } \\
(\mathrm{mg} / \mathrm{kg} d r y \text { soil })\end{array}$ & $\begin{array}{c}\text { Limit value for pollutant } \\
\text { transportation to } \\
\text { ground water } \\
(\mathrm{mg} / \mathrm{kg} d r y \text { soil })\end{array}$ \\
\hline $\mathrm{Pb}$ & 400 & 135 \\
\hline $\mathrm{Cd}$ & 70 & 27 \\
\hline $\mathrm{Cr}$ & 235 & 10 \\
\hline $\mathrm{Cu}$ & 3129 & 514 \\
\hline $\mathrm{Ni}$ & 1564 & 13 \\
\hline $\mathrm{Zn}$ & 23464 & 6811 \\
\hline
\end{tabular}

As seen in Table 4, $\mathrm{Pb}, \mathrm{Cd}, \mathrm{Cr}, \mathrm{Cu}, \mathrm{Zn}$ concentrations of measured samples are lower than national soil pollution regulations. But $\mathrm{Ni}$ concentrations of samples are higher than limit value for pollutant transportation to groundwater contamination. Heavy metal concentrations some different regions were adopted from Elmaslar et.al, [21] and given in Table 5. When we compare the average heavy metal values determined in soil samples of this study with the obtained results in the literature, it can be noted that heavy metal concentrations are similar with results obtained from the other studies.

Table 5. Heavy metal concentrations of soil samples in different studies

\begin{tabular}{|c|c|c|c|c|c|}
\hline Location & $\begin{array}{c}\mathbf{C u} \\
(\mathrm{mg} / \mathrm{kg} \\
()\end{array}$ & $\begin{array}{c}\mathbf{N i} \\
(\mathrm{mg} / \mathrm{kg}\end{array}$ & $\begin{array}{c}\mathbf{Z n} \\
(\mathrm{mg} / \mathrm{kg})\end{array}$ & $\begin{array}{c}\mathbf{P b} \\
(\mathrm{mg} / \mathrm{kg} \\
()\end{array}$ & $\begin{array}{c}\mathbf{C d} \\
(\mathrm{mg} / \mathrm{kg} \\
\mathrm{C}\end{array}$ \\
\hline $\begin{array}{c}\text { Industrial } \\
\text { area [22] }\end{array}$ & 21.520 & - & 42.710 & 0.380 & 0.121 \\
\hline Agricultira & & & & & \\
\hline 1 soil (0-30 & & & & & \\
\hline $\begin{array}{l}\mathrm{cm}), \\
\text { polluted } \\
\text { area, }\end{array}$ & 58.300 & - & $\begin{array}{c}338.00 \\
0\end{array}$ & 217.00 & 3.590 \\
\hline $\begin{array}{c}\text { Bulgaria } \\
\text { [23] }\end{array}$ & & & & & \\
\hline Industrial & & & & & \\
\hline $\begin{array}{c}\text { area, Hong } \\
\text { Kong } \\
{[24]}\end{array}$ & 26.100 & - & 62.80 & 87.700 & 1.310 \\
\hline Agricultira & & & & & \\
\hline $\begin{array}{l}1 \text { soil, } \\
\text { Manisa, }\end{array}$ & 14.300 & 22.300 & 6.750 & 27.300 & 2.800 \\
\hline $\begin{array}{c}\text { Turkey } \\
{[25]}\end{array}$ & & & & & \\
\hline Agricultira & & & & & \\
\hline $\begin{array}{l}1 \text { soil, } \\
\text { Menemen }\end{array}$ & 14.400 & 42.700 & 5.620 & 41.000 & 2.700 \\
\hline
\end{tabular}




\begin{tabular}{|c|c|c|c|c|c|}
\hline $\begin{array}{c}\text { Turkey } \\
\text { [25] }\end{array}$ & & & & & \\
\hline $\begin{array}{l}\text { Top soil, } \\
\text { Istanbul } \\
\text { City [21] }\end{array}$ & 30.500 & 44.500 & $\begin{array}{c}207.60 \\
0\end{array}$ & 17.700 & 0.460 \\
\hline
\end{tabular}

\section{$3.2 \mathrm{pH}$ and electrical conductivity analyses}

The results of $\mathrm{pH}$ concentrations and $\mathrm{EC}$ values are presented in Table 2 and 3 for the 16 parks on the Asian side of Istanbul, with regard to different sampling depths. For the activities of soil organisms and plant-availability of nutrients, the optimum $\mathrm{pH}$ level should be between 6-7 values. While plant growth is possible both below and above these $\mathrm{pH}$ values, there could be some disadvantages, therefore the soil nutrient deficiencies or potential toxicity could be predicted by observing the $\mathrm{pH}$ levels. As shown in Table 2 and Table 3, the $\mathrm{pH}$ values of soil samples vary within the scale of neutral (6.5-7.5) and slightly alkaline (7.5-8.5).

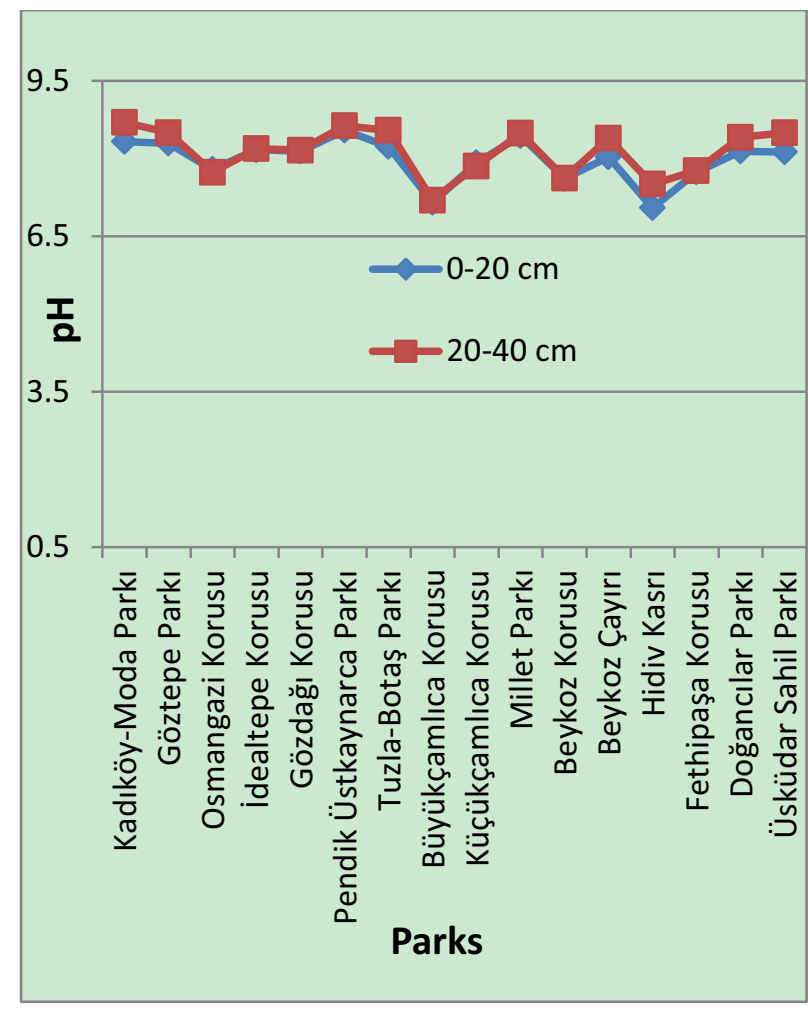

Figure 1. Variation of the $\mathrm{pH}$ values according to their locations and depths.

While the soil depths change between two levels, the $\mathrm{pH}$ levels appear to be stable regardless, i.e. there are no serious differences between $\mathrm{pH}$ values (Fig. 1). As is well known, organic and chemical fertilizers that are used as manure usually cause the increase of salt concentrations in soil, since they consist of dissolved materials. While the increase in concentration levels affects the osmotic pressure, this situation leads a dehydrational media where even if there is adequate water, the plants can not benefit. Additionally, a negative consequence of this situation is that the water within the plant can filtrate through the ground. As shown in Table 2 and 3 the investigated soil samples have a mean EC value of $173.274 \mu \mathrm{mhos} / \mathrm{cm}$ and
158. $649 \mu \mathrm{mhos} / \mathrm{cm}$ for shallow and deep data set, respectively. As shown in Fig. 2, EC values do not show significant differences except Hidiv Kasri. By these results it can be asserted that all soil samples belong to the salt-free soil class $(0-4000 \mu \mathrm{mhos} / \mathrm{cm})$ by the sense of the EC.

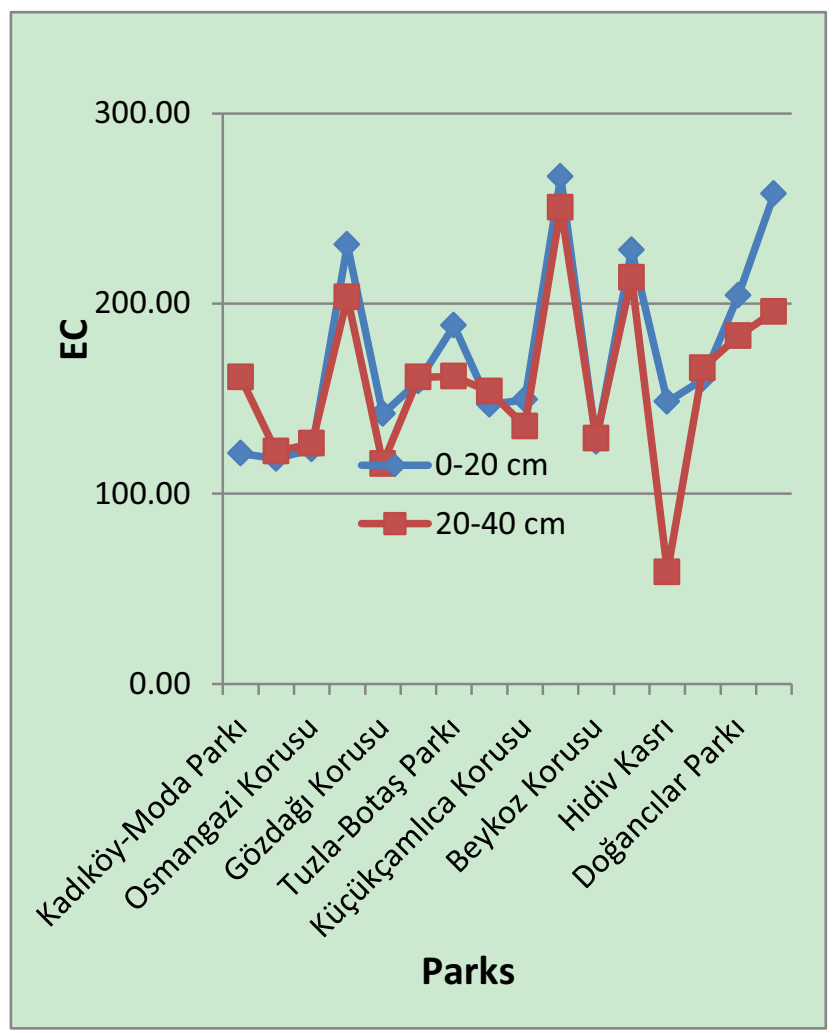

Figure 2. Variation of the EC results ( $\mu \mathrm{mhos} / \mathrm{cm}$ ) according to their locations and depths.

\subsection{Determination of correlation between heavy metals, $\mathrm{pH}$ and EC}

Correlation analysis method has been applied to the data set that is obtained from the experimental results of soil samples. The existence of a linear relationship between heavy metal concentrations, $\mathrm{pH}$ and $\mathrm{EC}$ values, were investigated. At this stage of statistical analysis, it was assumed that there would not be a mutual interaction between variables and there existed only a linear relationship. For this purpose, the widely used parametrical Pearson Correlation Analysis was employed to investigate the way of interaction, whilst the determinant coefficients were used to examine the strength of the relationship.

The existence of a relationship between two variables, and the direction of the relationship, can be examined by correlation and determination analysis. In this analysis, it is not taken into consideration whether the variables are dependent or independent variables. In scientific literature, correlation coefficients are usually grouped into parametric and non-parametric correlation coefficients. The most well-known non parametric correlation coefficients are Spearmen and Kendall 
coefficients. On the other hand, the most known and widely used parametric methods are the Pearson correlation coefficient [26]. The values of the Pearson correlation coefficient vary between -1 and +1 , the coefficient is about the values of zero when there is no linear relationship, and the close values to absolute one indicate that there is a strength relationship between two variables. Pearson's correlation coefficient between two variables is defined as the covariance of the two variables divided by the product of their standard deviations [27]. It must be pointed out that the Pearson correlation coefficient does not determine causalities, nor ascertain the presence of nonlinear relations, however, only linear relationship [28]. The Pearson correlation coefficient matrix of the dataset and the significance values of the correlations are presented in Table 6. Different depth observations have been merged into a dataset since there is not a significant difference between the results of different depth values.

Table 6. Correlation coefficients of $\mathrm{pH}, \mathrm{EC}$ and Heavy metal concentrations [29]

\begin{tabular}{|c|c|c|c|c|c|c|c|c|}
\hline & $p H$ & $E C$ & $C d$ & $\mathrm{Cr}$ & $\mathrm{Cu}$ & $N i$ & $P b$ & $Z n$ \\
\hline$p H$ & 1 & $\begin{array}{c}0,37 \\
7\end{array}$ & $\begin{array}{c}- \\
0,29 \\
5\end{array}$ & $\begin{array}{c}- \\
0,61 \\
1\end{array}$ & $\begin{array}{c}- \\
0,29 \\
8\end{array}$ & $\begin{array}{c}- \\
0,45 \\
1\end{array}$ & $\begin{array}{c}0,03 \\
7\end{array}$ & $\begin{array}{c}- \\
0,00 \\
3\end{array}$ \\
\hline $\begin{array}{c}\text { Sig. } \\
(2- \\
\text { tailed } \\
\quad)\end{array}$ & & $\begin{array}{c}0,03 \\
3\end{array}$ & $\begin{array}{c}0,10 \\
2\end{array}$ & 0 & $\begin{array}{c}0,09 \\
8\end{array}$ & 0,01 & $\begin{array}{c}0,84 \\
1\end{array}$ & $\begin{array}{c}0,98 \\
7\end{array}$ \\
\hline$E C$ & $\begin{array}{c}0,37 \\
7\end{array}$ & 1 & $\begin{array}{c}- \\
0,31 \\
5\end{array}$ & $\begin{array}{c}- \\
0,31 \\
9\end{array}$ & 0,06 & $\begin{array}{c}- \\
0,21 \\
5\end{array}$ & $\begin{array}{c}- \\
0,09 \\
8\end{array}$ & $\begin{array}{c}- \\
0,19 \\
2\end{array}$ \\
\hline $\begin{array}{l}\text { Sig. } \\
(2-\end{array}$ & 0,03 & & 0,07 & 0,07 & 0,74 & 0,23 & 0,59 & 0,29 \\
\hline tailed & 3 & & 9 & 5 & 3 & 8 & 3 & 2 \\
\hline$C d$ & $\begin{array}{c}- \\
0,29 \\
5\end{array}$ & $\begin{array}{c}0,31 \\
5\end{array}$ & 1 & $\begin{array}{c}0,21 \\
8\end{array}$ & $\begin{array}{c}0,63 \\
2\end{array}$ & $\begin{array}{c}0,55 \\
2\end{array}$ & $\begin{array}{c}0,62 \\
3\end{array}$ & $\begin{array}{c}0,83 \\
9\end{array}$ \\
\hline $\begin{array}{c}\text { Sig. } \\
(2- \\
\text { tailed } \\
\quad)\end{array}$ & $\begin{array}{c}0,10 \\
2\end{array}$ & $\begin{array}{c}0,07 \\
9\end{array}$ & & $\begin{array}{c}0,23 \\
1\end{array}$ & 0 & $\begin{array}{c}0,00 \\
1\end{array}$ & 0 & 0 \\
\hline $\mathrm{Cr}$ & $\begin{array}{c}- \\
0,61 \\
1\end{array}$ & $\begin{array}{c}- \\
0,31 \\
9\end{array}$ & $\begin{array}{c}0,21 \\
8\end{array}$ & 1 & $\begin{array}{c}0,38 \\
3\end{array}$ & $\begin{array}{c}0,75 \\
5\end{array}$ & $-0,12$ & $\begin{array}{c}0,08 \\
7\end{array}$ \\
\hline $\begin{array}{c}\text { Sig. } \\
(2- \\
\text { tailed } \\
)\end{array}$ & 0 & $\begin{array}{c}0,07 \\
5\end{array}$ & $\begin{array}{c}0,23 \\
1\end{array}$ & & 0,03 & 0 & $\begin{array}{c}0,51 \\
3\end{array}$ & $\begin{array}{c}0,63 \\
8\end{array}$ \\
\hline $\mathrm{Cu}$ & $\begin{array}{c}- \\
0,29 \\
8\end{array}$ & 0,06 & $\begin{array}{c}0,63 \\
2\end{array}$ & $\begin{array}{c}0,38 \\
3\end{array}$ & 1 & 0,67 & $\begin{array}{c}0,33 \\
5\end{array}$ & $\begin{array}{c}0,51 \\
4\end{array}$ \\
\hline $\begin{array}{c}\text { Sig. } \\
(2- \\
\text { tailed } \\
\quad)\end{array}$ & $\begin{array}{c}0,09 \\
8\end{array}$ & $\begin{array}{c}0,74 \\
3\end{array}$ & 0 & 0,03 & & 0 & $\begin{array}{c}0,06 \\
1\end{array}$ & $\begin{array}{c}0,00 \\
3\end{array}$ \\
\hline$N i$ & $\begin{array}{c}- \\
0,45 \\
1\end{array}$ & $\begin{array}{c}- \\
0,21 \\
5\end{array}$ & $\begin{array}{c}0,55 \\
2\end{array}$ & $\begin{array}{c}0,75 \\
5\end{array}$ & 0,67 & 1 & $\begin{array}{c}- \\
0,01 \\
1\end{array}$ & $\begin{array}{c}0,31 \\
7\end{array}$ \\
\hline $\begin{array}{c}\text { Sig. } \\
(2- \\
\text { tailed } \\
\quad\end{array}$ & 0,01 & $\begin{array}{c}0,23 \\
8\end{array}$ & $\begin{array}{c}0,00 \\
1\end{array}$ & 0 & 0 & & $\begin{array}{c}0,95 \\
3\end{array}$ & $\begin{array}{c}0,07 \\
7\end{array}$ \\
\hline
\end{tabular}

\begin{tabular}{|c|c|c|c|c|c|c|c|c|}
\hline $\mathrm{Pb}$ & $\begin{array}{c}0,03 \\
7\end{array}$ & $0, \overline{0}$ & $\begin{array}{c}0,62 \\
3\end{array}$ & $-0,12$ & $\begin{array}{c}0,33 \\
5\end{array}$ & 0,01 & 1 & $\begin{array}{c}0,80 \\
7\end{array}$ \\
\hline $\begin{array}{c}\text { Sig. } \\
(2- \\
\text { tailed } \\
\quad\end{array}$ & $\begin{array}{c}0,84 \\
1\end{array}$ & $\begin{array}{c}0,59 \\
3\end{array}$ & 0 & $\begin{array}{c}0,51 \\
3\end{array}$ & $\begin{array}{c}0,06 \\
1\end{array}$ & $\begin{array}{c}0,95 \\
3\end{array}$ & & 0 \\
\hline$Z n$ & $\begin{array}{c}- \\
0,00 \\
3\end{array}$ & $\begin{array}{c}- \\
0,19 \\
2\end{array}$ & $\begin{array}{c}0,83 \\
9\end{array}$ & $\begin{array}{c}0,08 \\
7\end{array}$ & $\begin{array}{c}0,51 \\
4\end{array}$ & $\begin{array}{c}0,31 \\
7\end{array}$ & $\begin{array}{c}0,80 \\
7\end{array}$ & 1 \\
\hline $\begin{array}{c}\text { Sig. } \\
(2- \\
\text { tailed } \\
\quad\end{array}$ & $\begin{array}{c}0,98 \\
7\end{array}$ & $\begin{array}{c}0,29 \\
2\end{array}$ & 0 & $\begin{array}{c}0,63 \\
8\end{array}$ & $\begin{array}{c}0,00 \\
3\end{array}$ & $\begin{array}{c}0,07 \\
7\end{array}$ & 0 & \\
\hline
\end{tabular}

As seen in Table 6, the correlation coefficient between $\mathrm{pH}-\mathrm{Cd}$ and $\mathrm{pH}-\mathrm{Cu}$ is $\mathrm{r}=-0.295$ and $\mathrm{r}=-0.298$, respectively indicating that there is an inverse low correlation. Furthermore, there are inverse relationships between the $\mathrm{pH}$ and all investigated heavy metals with the exception of $\mathrm{Pb}$. The lowest correlated parameters with $\mathrm{pH}$ are between $\mathrm{Zn}$ and $\mathrm{Pb}$, with a correlation coefficient $r=-0.003$ and $r=0.037$, respectively. These values are close to zero and negligible, thus for this dataset it can be concluded that the $\mathrm{pH}$ level is not influenced by $\mathrm{Zn}$ and $\mathrm{Pb}$ accumulation in park soils. On the other hand, the highest correlated parameter is $\mathrm{Cr}$. The correlation coefficient between $\mathrm{pH}$ and $\mathrm{Cr}$ is $\mathrm{r}=$ 0.611 . This value is between the range of $0.5<|\mathrm{r}|<0.9$ so it can be asserted that the power to influence the concentration of $\mathrm{Cr}$ by soil $\mathrm{pH}$ is at a moderate level. The correlation between $\mathrm{pH}$ and $\mathrm{Ni}$ is $\mathrm{r}=-0.451$, which is in low correlation zone $(0.0<|\mathrm{r}|<0.5)$.

The correlation coefficients between EC and heavy metal concentrations vary between a very low range $0.06<|\mathrm{r}|<0.319$, therefore it can be asserted that there is no significant relationships between EC values and heavy metal concentrations. From the perspective of heavy metal cross correlations $\mathrm{Cd}$ and $\mathrm{Zn}(\mathrm{r}=0.839), \mathrm{Cr}$ and $\mathrm{Ni}$ $(\mathrm{r}=0.755), \mathrm{Pb}$ and $\mathrm{Zn}(\mathrm{r}=0.807)$ have significant correlations.

\section{Conclusion}

By the results of this study the $\mathrm{pH}$ values of $0-20 \mathrm{~cm}$ samples vary between to 6.5-8.1 ranges, indicating that the soils belong to neutral and slightly alkaline soil types. As is known, in plant cultivation studies the preferred soil $\mathrm{pH}$ values range from $6.5-7.5$ since because of this range the plants could retrieve the needed nutrients easier. Since the $\mathrm{pH}$ values are over the edge value $(>7.5)$ in most parks (P1, P2, P4, P5, P6, P7, P10, P12, P15 and $P 16)$ it would be useful to include acidic fertilizers or sulfur the applications into the seasonal maintenance programs by terms of plant nutrition.

By examining the relationships with using correlation analysis between the heavy metal levels and EC and $\mathrm{pH}$ values it can be concluded that there lies a relationship between $\mathrm{pH}, \mathrm{Cr}$ and $\mathrm{Ni}$ levels. Similarly, there is a relationship between $\mathrm{Cd}, \mathrm{Pd}$ and $\mathrm{Zn}$ levels. For this data set the EC is found unrelated to each of the examined element levels. 
Having tested the various sites, heavy metal concentrations of the samples were found below the limit values that are set by the National Soil Pollution Control Regulation [30]. However, within such areas, heavy metals could accumulate in the soil surface or (and) could filtrate the soil over time and cause threatening levels of contamination. In order to prevent this situation, uncontrolled and excessive use of pesticides and chemical fertilizers, especially in seasonal maintenance programs, should be avoided.

\section{Acknowledgments}

This study, a part of master thesis entitled "The soil quality and heavy metal content analysis in some specified playing grounds of Istanbul Anatolian side" which conducted at Bahcesehir University Natural Science Institute.

\section{References}

1. G. Uyar, E. Avcil, M. Ören, F. Karaca, M.S. Öncel, Determination of Heavy Metal Pollution in Zonguldak (Turkey) by Moss Analysis (Hypnumcupressiforme) Environ Eng Sci 26(1):183194. doi: 10.1089/ees.2007.0253 (2009)

2. A. Sahmurova, H. Turkmenler, E.E. Özbas, Biosorption Kinetics and Isotherm Studies of Cd(II) by Dried Enteromorphacompressa Macroalgae Cells from Aqueous Solutions. Clean - Soil, Air, Water, 38(10):936-941. doi 10.1002/clen.201000108 (2010)

3. T.T.T. Duong, B.Y. Lee, Determining contamination level of heavy metals in road dust from busy traffic areas with different characteristics. J Environ Manage 92:554-562 (2011)

4. H. Zhu, X. Yuan, G. Zeng, M. Jiang, J. Liang, C. Zhang, J. Yin, H. Huang, Z. Liu, H. Jiang, Ecological risk assessment of heavy metals in sediments of Xia-wan Port based on modified potential ecological risk index. Trans Nonferrous Met Soc China 22:1470-1477. doi. 10.1016/S10036326(11)61343-5 (2012)

5. N. Çağlarırmak, Gıda güvenliğinin çevre kirliliği yönünden incelenmesi (in Turkish). 7th National Environmental Engineering Congress, 24-27 October 2007, İzmir, Turkey (2007)

6. S. Khan, Q. Cao, Y.M. Zheng, Y.Z. Huang, Y.G. Zhu, Health risks of heavy metals in contaminated soils and food crops irrigated with wastewater in Beijing, China. Environ Pollut 152:686-692 (2008)

7. F. Zeng, A. Shafaqat, H. Zhang, Y. Ouyang, B. Qiua, F. Wua, G. Zhang, The influence of $\mathrm{pH}$ and organic matter content in paddy soil on heavy metal availability and their uptake by rice plants. Environ Pollut 159:84-91 (2011)

8. A.I. Amouei, Z. Yousefi, A.H. Mahvi, K. Naddafi, M. Tahmasbizadeh, Heavy metal concentrations in industrial, agricultural, and highway soils in northern Iran. Environmental Justice 5(3):153-157. doi:10.1089/env.2011.0038 (2012)
9. O. Mikanova, Effects of heavy metals on some soil biological parameters, J Geochem Explor 88:220-223 (2006)

10. O. Morton-Bermea, M.B. Alvarez, E.H. Gaso, N. Segovia, Heavy metal concentrations in surface soils from Mexico City. Bull Environ Contam Toxicol 68(3): 383-388. doi 10.1007/s001280265 (2002)

11. C. Kabala, C. Tadeusz, S. Leszek, Factors influencing the concentration of heavy metals in soils of allotment gardens in the city of Wroclaw, Poland. Fresenius Environ Bull 18(7):1118-1124 (2009)

12. S. Rajan, N.N.M. Firdaus, M. Appukutty, K. Ramasamy, Effects of climate changes on dissolved heavy metal concentrations among recreational park tributaries in Pahang, Malaysia. Biomed Res-India 23(1):23-30 (2012)

13. H. Arslan, H. Gunal, M. Guler, Assessment the soil properties affecting salinity and sodicity of Bafra plain using multivariate statistical techniques. Carpat J Earth Env 8(1):81-90 (2013)

14. X. Liu, L. Sun, S. Chen, Heavy metal pollution of soil around the gangue hill: a case study from Zhuxiangzhuang coal mine, northern Anhui Province, China. International Conference on Energy, Environment and Sustainable Development October 21-23, 2011, Shangai, China (2012)

15. M. Shahbaz, M.Z. Hashmi, R.N. Malik, A. Yasmin, Relationship between heavy metals concentrations in egret species, their environment and food chain differences from two Headworks of Pakistan. Chemosphere 93:274-282 doi: 10.1016/j.chemosphere.2013.04.078 (2013)

16. Y. Zheng, Q. Gao, X. Wen, Multivariate statistical analysis of heavy metals in foliage dust near pedestrian bridges in Guangzhou, South China in 2009. Environ Earth Sci 70(1):107-113. doi 10.1007/s12665-012-2107-z (2013)

17. TUIK, Turkish Statistical Institute, Official newsletter. No: 16. January (2012)

18. M. Buyukyildiz, The Soil Quality and Heavy Metal Content Analysis in Some Specified Playing Grounds of Istanbul Anatolian Side. Master Thesis, Bahcesehir University, Urban Systems and Transport Management Program (2013)

19. TS ISO 11464. Soil quality; pretreatment of samples for physicochemical analyses.

20. EPA, Test Methods for Evaluating Soil Waste. Microwave Assisted Acid Digestion of sediments, sludges, soils and oils, January.3051A-1 (1998)

21. E.E. Ozbas, H.K. Ozcan, N. Balkaya, G. Demir, C. Bayat, Heavy Metal Amounts in Soil and Sediments of Surface Water Sources in the Industrial Regions of Istanbul. J Residuals Sci Tech 4(2):89-94 (2007)

22. B. Skrbic, and S. Cupic, Trace Metal Distribution in Surface Soils of Novi Sad and Bank Sediment of the Danube River. J. Environ. Sci. Health Part A. A39 (6)1547-1558 (2004)

23. P. Bojinova, B. Georgiev, I. Kabakchiev, V. Krasteva, L. Stanislavova, H. Tchuldjian, G. Welp, and G. Brummer, Harmonization of the Methods for the Investigation of Heavy Metal Pollution of Soils and the Standardization of the Assessment Criteria 
for Soil Protection. Report No. UBA-FB 96-071. Terytze, K.N. ed., Poushkarov Institute of Soil Science and Agroecology, Sofia and Institut fur Bodenkunde: Bonn, (1996)

24. T.B. Chen, J.W.C. Wong, H.Y. Zhou, and M.H. Wong, Assessment of Trace Metal Distribution and Contamination in Surface Soils of Hong Kong. Environ. Pollut. 96, 61-68, (1997)

25. O.L. Elmaci, S. Delibacak, M. Secer, and A. Bodur, Fertility Status, Trace Elements and Heavy Metal Pollution of Agricultural Land Irrigated from the Gediz River., Int. J. Water. 2, Nos.2/3, (2002)

26. J.L. Myers, A.D. Well, Research Design and Statistical Analysis (2nd ed.), Lawrence Erlbaum, p. 508, ISBN 0-8058-4037-0 (2003)
27. C.L. Joseph, K.W. Kevin, L.Y. Wan, Solar radiation modeling using ANNs for different climates in China. Energy Convers Manage 49:1080-1090. doi 0.1016/j.enconman.2007.09.021 (2008)

28. J. Duricic, T. Erdik, A.O. Pektaş, P.H.A.J.M. Van Gelder, Mean normalized force computation for different types of obstacles due to dam break using statistical techniques. Water 5:560-577. doi:10.3390/w5020560 (2013)

29. SPSS Algorithm, IBM SPSS Statistics 20 Algorithms, Copyright IBM Corporation, 1989, USA (2011)

30. TKKY, National Regulations of soil pollution control Turkish Official Gazette, No 27605, Turkey (2010) 